\title{
Nodulation and biological nitrogen fixation in soybean (Glycine max L.) as influenced by phosphorus fertilization and arbuscular mycorrhizal inoculation
}

\author{
Adeniyi Adebowale Soretire, ${ }^{1 *}$ Nurudeen Olatunbosun Adeyemi, ${ }^{2}$ \\ Muftau Olaoye Atayese, ${ }^{2}$ Olalekan Suleiman Sakariyawo, ${ }^{2}$ \\ Ademola Adewunmi ${ }^{1}$ \\ ${ }^{1}$ Department of Soil Science and Land Management, Federal University of Agriculture, \\ Abeokuta, Ogun State, Nigeria \\ ${ }^{2}$ Department of Plant Physiology and Crop Production, Federal University of Agriculture, \\ Abeokuta, Ogun State, Nigeria. \\ *corresponding author, e-mail: soretirea@gmail.com
}

Manuscript received: 12 February 2020; revised: 01 March 2010; accepted: 29 March 2020

\begin{abstract}
Arbuscular mycorrhizal fungi (AMF) can be used to promote the productivity of legumes on phosphorus- (P) deficient soils. The present study investigates the inoculation effects of three AMF species (Funneliformis mosseae, Rhizophagus intraradices, and Claroideoglomus etunicatum) and the control (uninoculated) on nitrogen fixation efficiency and growth performance of tropical soybean cultivar (TGx1448-2E) under varying $\mathrm{P}$ fertilizer rates $\left(0,20\right.$, and $\left.40 \mathrm{~kg} \mathrm{P}_{2} \mathrm{O}_{5} \mathrm{ha}^{-1}\right)$ in a derived savannah of Nigeria. The results showed that shoot and root dry matter, number of nodules, relative ureide abundance (RUA), nitrogen derived from atmosphere (Ndfa), total $\mathrm{N}$ fixed, shoot $\mathrm{P}$ uptake, grain, and biomass yield significantly increased with AMF inoculation, with better performance observed in plants inoculated with Rhizophagus intraradices and Funneliformis mosseae compared to Claroideoglomus etunicatum. Similarly, the soybean growth variables, $\mathrm{P}$ uptake, and nitrogen fixation activities increased with increasing $\mathrm{P}$ application rates. Conversely, AMF root colonization significantly reduced with increasing $\mathrm{P}$ rate. Interaction of $\mathrm{AMF}$ inoculation and $\mathrm{P}$ rates significantly influenced soybean growth and nitrogen fixation. $R$. intraradices inoculation with $20 \mathrm{~kg} \mathrm{P}_{2} \mathrm{O}_{5} \mathrm{ha}^{-1}$ resulted in the highest amount of RUA, Ndfa, N fixed, and grain yield. It could be concluded from this study that $R$. intraradices with moderate $\mathrm{P}$ rate could be used to enhance nodulation, nitrogen fixation, and soybean yield in P-deficient soils.
\end{abstract}

Keywords: biological nitrogen fixation, mycorrhizal fungi isolates, phosphorus uptake, ureide assay, soybean productivity 


\section{Introduction}

Legumes (Fabaceae) are important crops in agriculture with abundant levels of proteins and oils for both human and livestock consumption. They do great service to the sustainability of most agricultural systems. Their symbiotic relationship with soil rhizobia helps them in the fixation of atmospheric dinitrogen $\left(\mathrm{N}_{2}\right)$, thus reducing the intensive application of inorganic nitrogen $(\mathrm{N})$ fertilizers on agricultural soils while maintaining soil fertility for sustainable crop production. Soybean (Glycine max L. Merrill) is an important oil-seed legume cultivated in many parts of the world, including Nigeria [1]. However, low phosphorus (P) availability is the major factor limiting legume productivity in most tropical soils [2]. The nitrogen fixation process in legumes is highly sensitive to adverse environmental conditions, $P$ deficiency [3]. This has become crucial because the way $\mathrm{N}_{2}$ fixation in soybean is affected by $\mathrm{P}$ deficiency is not fully explored under field conditions. Therefore, a better understanding of the responses of $\mathrm{N}_{2}$-fixation in soybean in P-deficient soils is urgently needed for promoting soybean production towards achieving food security, particularly in sub-Saharan Africa.

Phosphorus plays an important role in the regulation of many metabolic processes in plants, including photosynthesis and $\mathrm{N}_{2}$ fixation $[4,5]$. Nevertheless, $\mathrm{P}$ deficiency has negative implications on nodule functioning in legumes $[6,7]$ due to the high $\mathrm{P}$ demand in $\mathrm{N}_{2}$-fixating nodules for optimal functioning and cell energy metabolism $[3,8]$. In addition, the amount of carbon delivered to the nodules and the absorption of ureides in the nodules are reduced under $\mathrm{P}$ deficiency $[9,10]$. The report of [11] showed that $\mathrm{P}$ application positively influenced $\mathrm{N}_{2}$ fixation in legumes with increased $\mathrm{N}$ content. Hence, an adequate $\mathrm{P}$ availability in the nodules is essential for $\mathrm{N}_{2}$ fixation in P-deficient soils.

The intensive use of inorganic $\mathrm{P}$ fertilizers has been widely promoted in most agro-ecosystems to maintain a sufficient level of $\mathrm{P}$ for crop productivity [12]. The recovery of $\mathrm{P}$ application is reported to be very low (10-30\% of the fertilizer $\mathrm{P}$ applied) [13]. In addition, most farmers in sub-Saharan Africa are resource-limited and may not be able to afford the high $\mathrm{P}$ fertilizer cost. Moreover, excessive use of $\mathrm{P}$ fertilizer may lead to environmental pollution due to the eutrophication of underground waters and the contamination of soils with heavy metals. There is also report of the potential scarcity of $\mathrm{P}$ fertilizers due to the rapid depletion of phosphate rocks. In the context of sustainable agriculture and global $\mathrm{P}$ crisis faced by farmers, arbuscular mycorrhizal fungi (AMF) are essential components of sustainable soil-plant systems, forming symbiotic relationships with most plants, including legumes [14]. AMF stimulate the growth of the host plants through increase in soil inorganic nutrients' uptake, particularly $\mathrm{P}[14,15]$. With reduction in the application of chemical $\mathrm{P}$ fertilizers, 
they could play an important role in meeting the food requirements of an increasing human population $[16,17]$. In legumes, AMF has been reported to promote growth and yield performance in soils with low $\mathrm{P}$ availability $[18,19$, 20]. With increased number of nodules and size, AMF have positive effect on nodulation [21]. The co-inoculation of AMF and rhizobia is reported to promote $\mathrm{N}_{2}$ fixation in legumes [22]. Nevertheless, the symbiotic contribution of different AMF isolates on $\mathrm{N}_{2}$ fixation in legumes has not been fully explored, particularly in a derived savannah of Nigeria with low soil phosphorus availability. The potential of AMF in promoting $\mathrm{P}$ uptake in host plants under low $\mathrm{P}$ availability could be explored within the context of enhancing nodulation and biological nitrogen fixation in soybean grown on P-deficient soils in this agro-ecology.

The present study will help in understanding how AMF inoculation could promote the symbiotic nitrogen-fixing ability of a promiscuous soybean cultivar (TGx 1448-2E) on P-deficient soils. Thus, this study hypothesized that AMF would enhance the nodulation, nitrogen fixation, and growth performance of soybean on P-deficient soils. Hence, this study aimed to investigate the effects of AMF inoculation with three AMF (Funneliformis mosseae, Rhizophagus intraradices, and Claroideoglomus etunicatum) isolates on the nodulation, nitrogen fixation, and yield performance of soybean plants under different soil $\mathrm{P}$ availabilities.

\section{Materials and methods}

\section{Study site}

The experiment was carried out at the experimental field of the Federal University of Agriculture Research Farm, Abeokuta, Southwest Nigeria (latitude $7^{\circ} 15^{\prime} \mathrm{N}$, longitude $3^{\circ} 28^{\prime} \mathrm{E}$ ) in the 2017 cropping season. The initial soil properties were determined using standard methods (Table 1). A bulk soil sample was collected before planting to determine the physico-chemical properties of the soil using standard protocols. The soil properties determined were soil $\mathrm{pH}$ (1:1 soil: water) using glass electrode $\mathrm{pH}$ meter [23], organic carbon using the WalkleyBlack method as modified by [24], total nitrogen using the micro-Kjeldahl distillation method [25], available phosphorus using Bray-1 [26] and determined colorimetrically using the method of [27]. The exchangeable bases were extracted with $1 \mathrm{~N}$ ammonium acetate ( $\mathrm{IN} \mathrm{NH}_{4} \mathrm{OA}_{\mathrm{C}}$ ), buffered at $\mathrm{pH}$ of 7 , and soil particle size distribution was determined using the hydrometer method [28]. The initial AMF spore count was determined using the wet sieving method [29]. 


\section{Experimental treatments and design}

The study consisted of four levels of AMF inoculation (non-AMF (control), Funneliformis mosseae, Rhizophagus intraradices, and Claroideoglomus etunicatum) and three $\mathrm{P}$ fertilizer rates $\left(0,20\right.$, and $\left.40 \mathrm{~kg} \mathrm{P}_{2} \mathrm{O}_{5} \mathrm{ha}^{-1}\right)$ laid in a splitplot design with three replications. The plot size was $4 \mathrm{~m} \times 4 \mathrm{~m}$.

Source of experimental materials, sowing, and AMF inoculation

Pure AMF inocula ( $F$. mosseae, $R$. intraradices, and $C$. etunicatum) were obtained from the International Institute of Tropical Agriculture, Ibadan, Nigeria. The inocula were multiplied in sterilized sand, using single-plant culture of maize (Zea mays L.) for four months consisting of spores, hyphae, and colonized root pieces. Soybean seeds (TGx 1448-2E) were obtained from the Institute of Agricultural Research and Training, Ibadan, Nigeria.

The field was prepared by ploughing followed by harrowing. The plots were marked out with ropes and pegs and then labelled. The seeds were sown at a depth of $2-5 \mathrm{~cm}$ and a spacing of $50 \mathrm{~cm} \times 10 \mathrm{~cm}$ on 20 July 2017 . AMF inoculum (10 g) was applied to the planting hole before sowing. Phosphorus was supplied through single superphosphate at the time of sowing.

\section{Data collection}

\section{Dry matter accumulation and nodulation}

Ten plants were randomly harvested from the net plot at the early pod filling stage and separated into leaf, stem + petiole, root, and nodules. The samples were oven-dried at $70{ }^{\circ} \mathrm{C}$ for $72 \mathrm{hrs}$ to determine the dry weights using a precision measuring scale. The number of nodules was counted, and the average number of nodules per plant was determined.

\section{Estimation of relative ureide abundance and biological nitrogen fixation}

The $\mathrm{N}_{2}$ fixation in the soybean cultivars was measured during the early podfilling stage using the xylem ureide assay method [30]. Blended subsamples of stem + petiole $(0.5 \mathrm{~g})$ were used to extract the xylem solutes in boiling water, and the ureide and nitrate concentration were measured according to the procedures of [31]) and [32]. The blended plant samples were digested in concentrated hot acid $\left(\mathrm{H}_{2} \mathrm{SO}_{4}\right)$, and the total $\mathrm{N}$ content was determined colorimetrically using automated analysis. The relative ureide- $\mathrm{N}$ of the sample was calculated using the equation: 


$$
\text { Relative ureide }-\mathrm{N}(\%)=\frac{4 \times \text { ureide }}{[(4 \times \text { ureide })+\text { nitrate }]} \times 100
$$

The standard curve relating the proportion of $\mathrm{N}$ derived from $\mathrm{N}_{2}$ fixation (Ndfa\%) to RU-N for soybean during pod filling was obtained using the equation below:

$$
x=10.7+0.50 P+0.0034 P^{2},
$$

where $\mathrm{P}$ is $\mathrm{N}$ derived from atmosphere (\% Ndfa), and $\mathrm{x}$ is the ureide- $\mathrm{N}$.

The shoot $\mathrm{N}\left(\mathrm{kg} \mathrm{ha}^{-1}\right)$ was calculated using the equation below:

Shoot $\mathrm{N}\left(\mathrm{kg} \mathrm{ha}^{-1}\right)=[$ shoot $\mathrm{N}$ concentration $(\%) \times$ shoot dry matter $(\mathrm{kg} / \mathrm{ha})]$

Total $\mathrm{N}$ was calculated by multiplying with a factor of 1.5 [33].

$$
\text { Crop } \mathrm{N}\left(\mathrm{kg} \mathrm{ha}^{-1}\right)=(\text { Shoot } \mathrm{N} \times 1.5)
$$

The amount of $\mathrm{N}_{2}$ fixed was calculated using the equation below:

$$
\text { Amount of } \mathrm{N}_{2} \text { fixed }\left(\mathrm{kg} \mathrm{ha}^{-1}\right)=(\% \mathrm{Ndfa} \times \text { Crop } \mathrm{N})
$$

\section{Estimation of AMF root colonization}

Root colonization by AMF was measured according to [34]. The preserved root samples were cleared in hot $\mathrm{KOH}$ solution $\left(10 \% \mathrm{w} / \mathrm{v}\right.$, at $\left.90^{\circ} \mathrm{C}\right)$ for 1 hour and stained with trypan blue lacto-glycerol $(1: 1: 1: 0.5 \mathrm{~g})$ at $90^{\circ} \mathrm{C}$ for 30 minutes. The AMF colonization (RLC) was determined as the percentage of root length colonized by AMF was calculated [20].

$$
R L C=\frac{\text { Number of colonized roots }}{\text { Total number of roots }} \times 100
$$

\section{Grain yield}

At harvest maturity, the plants were harvested from the plots, threshed, and air-dried to estimate the grain yield per hectare. 


\section{Statistical analysis}

The data collected were subjected to two-way analysis of variance (ANOVA) with Genstat Release 12.1 (Copyright 2009, VSN International Ltd). Duncan's multiple range test was used to separate treatment means at 5\% probability level. Data expressed as percentages and relative to counts were arcsine-square-root and $\log (x+1)$ transformed.

Table 1. Soil physical and chemical properties of the experimental site

\begin{tabular}{lc}
\hline Soil Property & Value \\
\hline Texture & Sandy loam \\
Sand $\left(\mathrm{g} \mathrm{kg}^{-1}\right)$ & 707.5 \\
$\mathrm{Silt}\left(\mathrm{g} \mathrm{kg}^{-1}\right)$ & 127.5 \\
$\mathrm{Clay}\left(\mathrm{g} \mathrm{kg}^{-1}\right)$ & 165.0 \\
$\mathrm{pH}\left(\mathrm{H}_{2} \mathrm{O}\right)$ & 5.70 \\
Organic Matter (\%) & 1.78 \\
Nitrogen $(\%)$ & 0.09 \\
Available Phosphorus $\left(\mathrm{mg} \mathrm{kg}^{-1}\right)$ & 6.13 \\
Potassium $(\mathrm{cmol} \mathrm{kg})$ & 0.61 \\
Calcium $\left(\mathrm{cmol} \mathrm{kg}^{-1}\right)$ & 6.68 \\
Magnesium $\left(\mathrm{cmol} \mathrm{kg}^{-1}\right)$ & 1.47 \\
Sodium $(\mathrm{cmol} \mathrm{kg})$ & 0.29 \\
Total Exchangeable Acidity $\left(\mathrm{cmol} \mathrm{kg}^{-1}\right)$ & 0.11 \\
Cation Exchange Capacity $\left(\mathrm{cmol} \mathrm{kg}^{-1}\right)$ & 9.17 \\
\hline
\end{tabular}

\section{Results}

\section{Dry matter accumulation}

Phosphorus application and AMF inoculation had significant effect on the shoot and root dry matter of the soybean (Table 2). The shoot and root dry matter increased with $\mathrm{P}$ fertilizer application compared to the control (no P fertilizer added); however, no significant differences were recorded between the application of 20 and $40 \mathrm{~kg} \mathrm{P}_{2} \mathrm{O}_{5} \mathrm{ha}^{-1}$ (Table 3). AMF inoculation significantly increased the shoot and root dry matter over non-AMF treatment (Table 3). The increase in shoot and root dry matter induced by F. mosseae (20.6 and 16.9\%) and $R$. intraradices (23.9 and $15 \%$ ) over non-AMF treatment was significantly greater than that obtained with $C$. etunicatum (9.3 and 5.2\%). There was a 
significant interaction effect of $\mathrm{P}$ application and AMF inoculation on the shoot and root dry matter of the soybean plant (Table 2). Soybean inoculated with $R$. intraradices with $20 \mathrm{~kg} \mathrm{P}_{2} \mathrm{O}_{5}$ ha $^{-1}$ fertilizer rate significantly had the highest shoot and root dry matter, followed by inoculation with $F$. mosseae at $20 \mathrm{~kg} \mathrm{P}_{2} \mathrm{O}_{5} \mathrm{ha}^{-1}$ application rate and then $40 \mathrm{~kg} \mathrm{P}_{2} \mathrm{O}_{5} \mathrm{ha}^{-1}$ fertilizer application alone (figures 1a and b). With high $\mathrm{P}$ fertilizer application $\left(40 \mathrm{~kg} \mathrm{P}_{2} \mathrm{O}_{5}\right.$ ha $\left.^{-1}\right)$, the shoot and root dry matter decreased, but no significant difference was observed between the AMF isolates and non-AMF treatments (figures $1 \mathrm{a}$ and $\mathrm{b}$ ).

\section{Nodulation}

The results showed that $\mathrm{P}$ fertilizer application rates and AMF inoculation had significant effect on the number of nodules of soybean but not on the nodule dry weight (Table 2). The number of nodules increased with the application of 20 and $40 \mathrm{~kg} \mathrm{P}_{2} \mathrm{O}_{5} \mathrm{ha}^{-1}$ rates (58.6 and $60.2 \%$ respectively), but no significant difference was observed between the two rates (Table 3). Soybean inoculated with $R$. intraradices significantly had the highest number of nodules compared to other AMF isolates and non-AMF treatment (Table 3). A significant interaction between $\mathrm{P}$ fertilizer application rates and AMF inoculation was observed for the number of nodules of soybean (Table 2). The lowest number of nodules was recorded in non-AMF soybean plants and no $\mathrm{P}$ fertilizer application, while the highest number of nodules was recorded in plants inoculated with $R$. intraradices with $20 \mathrm{~kg} \mathrm{P}_{2} \mathrm{O}_{5} \mathrm{ha}^{-1}$ rate (Figure 2).

Table 2. Mean squares for the effect of $\mathrm{P}$ fertilizer application $(\mathrm{P})$ and mycorrhizal inoculation $(\mathrm{M})$ and their interactions $(\mathrm{P} \times \mathrm{M})$ on dry matter accumulation and nodulation in soybean

\begin{tabular}{lccccc}
\hline & df & $\begin{array}{c}\text { Shoot dry } \\
\text { weight } \\
\left(\text { g plant }^{-1}\right)\end{array}$ & $\begin{array}{c}\text { Root dry } \\
\text { weight } \\
\left(\text { g plant }^{-1}\right)\end{array}$ & $\begin{array}{c}\text { Number of } \\
\text { nodules } \\
\left(\text { plant }^{-1}\right)\end{array}$ & $\begin{array}{c}\text { Nodule } \\
\text { dry weight }_{\left(\text {plant }^{-1}\right)}\end{array}$ \\
\hline Reps & 1 & 11.8 & 0.016 & 102.1 & 0.029 \\
P rates (P) & 2 & $20.1 * *$ & $0.33^{* *}$ & $674.6^{* *}$ & $0.061^{\mathrm{ns}}$ \\
Error a & 2 & 0.09 & 0.005 & 7.72 & 0.014 \\
AMF (M) & 3 & $10.2^{* * *}$ & $0.12^{* * *}$ & $190.9^{* * *}$ & $0.027^{\mathrm{ns}}$ \\
P $\times$ M & 6 & $7.32^{* *}$ & $0.091^{* * *}$ & $96.8^{* * *}$ & $0.019^{\mathrm{ns}}$ \\
Error b & 9 & 0.09 & 0.003 & 2.84 & 0.011 \\
Total & 23 & & & &
\end{tabular}

Notes: *,**,*** indicate significance at $0.05,0.01$, and 0.001 probability level respectively; ns indicates not significant. 
Table 3. Effects of $\mathrm{P}$ fertilizer application (P) and mycorrhizal inoculation (M) on dry matter accumulation and nodulation in soybean

\begin{tabular}{|c|c|c|c|c|}
\hline & $\begin{array}{c}\text { Shoot dry } \\
\text { weight } \\
\left(\text { g plant }^{-1}\right)\end{array}$ & $\begin{array}{c}\text { Root dry } \\
\text { weight } \\
\left(\text { g plant }^{-1}\right) \\
\end{array}$ & $\begin{array}{c}\text { Number } \\
\text { of nodules } \\
\left(\text { plant }^{-1}\right)\end{array}$ & $\begin{array}{c}\text { Nodule dry } \\
\text { weight } \\
\left(\text { g plant }^{-1}\right)\end{array}$ \\
\hline \multicolumn{5}{|l|}{$P$ rates $(P)$} \\
\hline $0 \mathrm{~kg} \mathrm{ha}^{-1}$ & 8.75 & 1.39 & 10.9 & 0.19 \\
\hline $\begin{array}{l}20 \mathrm{~kg} \mathrm{ha}^{-1} \\
40 \mathrm{~kg} \mathrm{ha}^{-1}\end{array}$ & $\begin{array}{l}11.6 \\
11.4\end{array}$ & $\begin{array}{l}1.73 \\
1.76\end{array}$ & $\begin{array}{l}26.3 \\
27.4\end{array}$ & $\begin{array}{l}0.35 \\
0.32\end{array}$ \\
\hline $\operatorname{Lsd}(\mathrm{p}<0.05)$ & 0.67 & 0.15 & 5.97 & ns \\
\hline \multicolumn{5}{|c|}{ AMF inoculation } \\
\hline Non-AMF & 9.05 & 1.47 & 15.0 & 0.22 \\
\hline F. mosseae & 11.4 & 1.77 & 24.6 & 0.37 \\
\hline$R$. intraradices & 11.9 & 1.73 & 27.6 & 0.31 \\
\hline C. etunicatum & 9.98 & 1.55 & 18.9 & 0.24 \\
\hline $\operatorname{Lsd}(\mathrm{p}<0.05)$ & 0.39 & 0.07 & 2.20 & ns \\
\hline
\end{tabular}

Note: ns indicates non-significant differences at $\mathrm{p}$ value $<0.05$.

a.

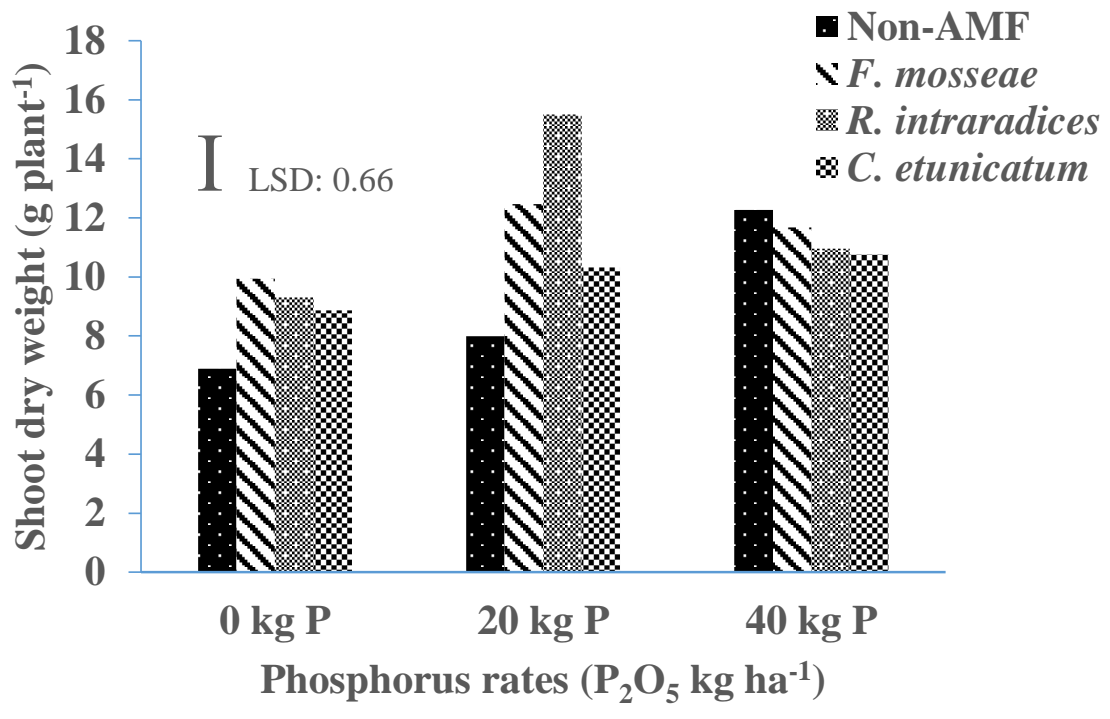


b.

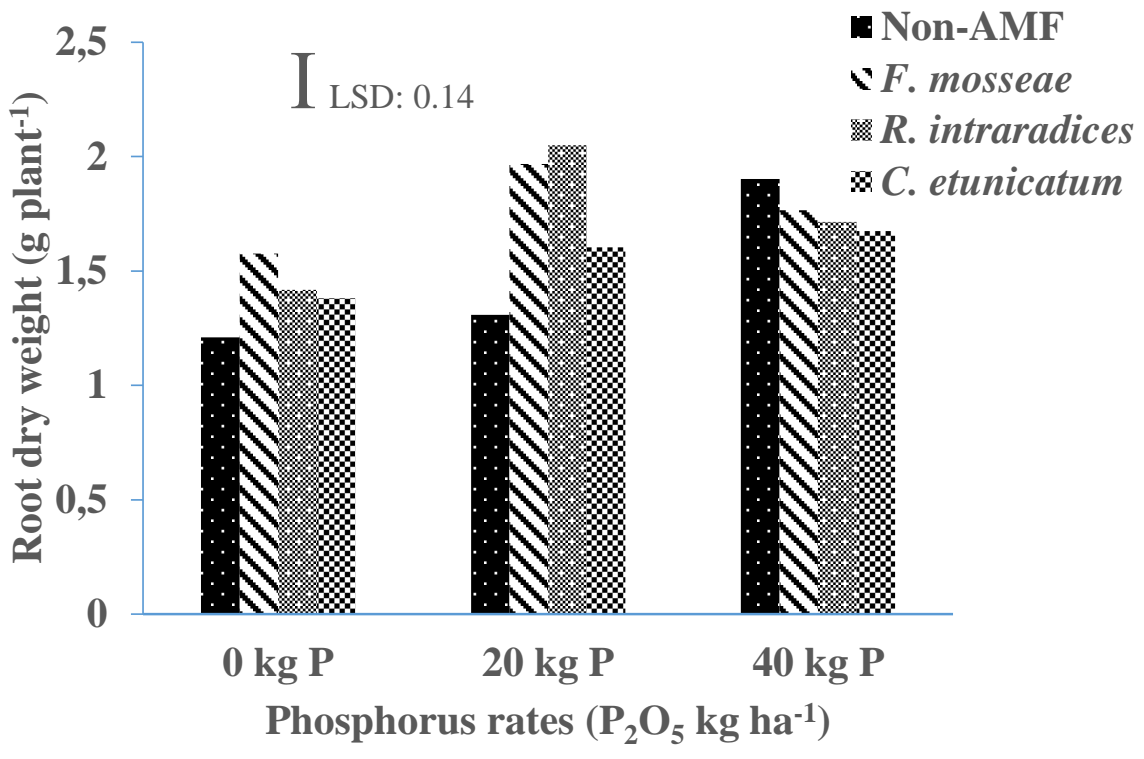

Figure 1. Interactive effect of phosphorus rates and AMF inoculation on (a) shoot dry weight and (b) root dry weight of soybean. Bar denotes Lsd value at $5 \%$ probability level.

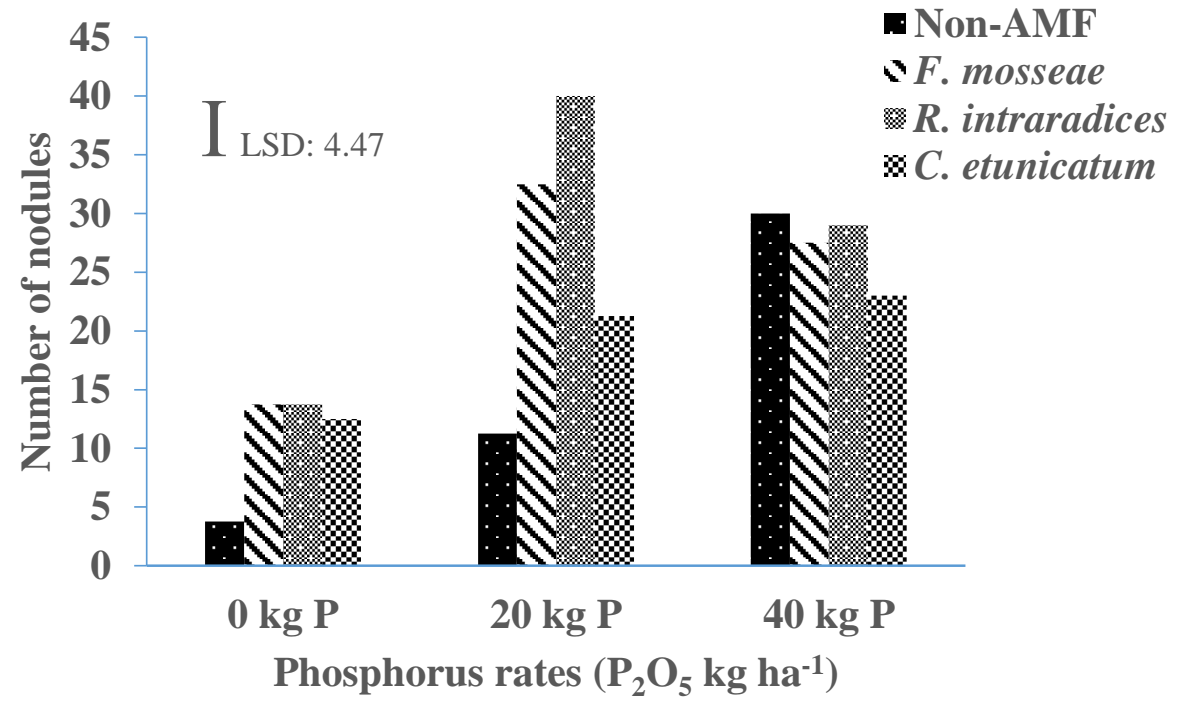

Figure 2. Interactive effect of phosphorus rates and AMF inoculation on the number of nodules of soybean. Bar denotes Lsd value at 5\% probability level. 


\section{Nitrogen fixation}

The $\mathrm{P}$ fertilizer application had significant effect on the relative abundance of ureide- $\mathrm{N}$ and the amount of nitrogen fixed by the soybean plant but not on concentrations of nitrate- $\mathrm{N}\left(\mathrm{NO}_{3}-\mathrm{N}\right)$ and ureide- $\mathrm{N}$ and the proportion of $\mathrm{N}$ derived from atmosphere (Ndfa) (Table 4). The relative ureide- $\mathrm{N}$ and the amount of $\mathrm{N}$ fixed increased with increase in $\mathrm{P}$ rates (Table 5). However, there was no significant difference between the application of 20 and $40 \mathrm{~kg} \mathrm{P}_{2} \mathrm{O}_{5} \mathrm{ha}^{-1}$ rates (Table 5). The concentration of nitrate- $\mathrm{N}$ was recorded to decrease with increase in $\mathrm{P}$ rates, while ureide- $\mathrm{N}$ and $\mathrm{Ndfa}$ increased with increase in $\mathrm{P}$ rates; however, no significant difference was observed among the $\mathrm{P}$ rates (Table 5).

The concentrations of nitrate- $\mathrm{N}\left(\mathrm{NO}_{3}-\mathrm{N}\right)$ and ureide- $\mathrm{N}$, the relative abundance of ureide- $\mathrm{N}$, the proportion of $\mathrm{N}$ derived from atmosphere (Ndfa), and the amount of $\mathrm{N}$ fixed in the soybean plant were significantly influenced by AMF inoculation (Table 4). Significant differences were observed among the AMF isolates and the non-AMF treatments regarding these parameters (Table 5). The Funneliformis mosseae and $R$. intraradices inoculation effects were significantly higher than in the case of $C$. etunicatum. Soybean inoculated with $F$. mosseae had the highest concentrations of nitrate- $\mathrm{N}$ and ureide- $\mathrm{N}$ in the soybean, while those inoculated with $R$. intraradices had the highest relative ureide-N, Ndfa, and the amount of $\mathrm{N}$ fixed in soybean (Table 5).

Table 4. Mean squares for the effect of $\mathrm{P}$ fertilizer application $(\mathrm{P})$ and mycorrhizal inoculation $(\mathrm{M})$ and their interactions $(\mathrm{P} \times \mathrm{M})$ on the concentration of nitrate, ureide, relative ureide- $\mathrm{N}$, the proportion of $\mathrm{N}$ derived from atmosphere, and the amount of $\mathrm{N}$ fixed in soybean

\begin{tabular}{lcccccc}
\hline & Df & $\begin{array}{c}\text { Nitrate N } \\
(\mu \mathrm{mol})\end{array}$ & $\begin{array}{c}\text { Ureide-N } \\
(\mu \mathrm{mol})\end{array}$ & $\begin{array}{c}\text { Relative } \\
\text { ureide-N } \\
(\%)\end{array}$ & $\begin{array}{c}\text { Ndfa } \\
(\%)\end{array}$ & $\begin{array}{c}\text { Amount of N } \\
\text { fixed } \\
\left(\mathrm{kg} \mathrm{ha}^{-1}\right)\end{array}$ \\
\hline Reps & 1 & 0.002 & 2.91 & 5.33 & 5.12 & 30.01 \\
P rates (P) & 2 & $0.029^{\mathrm{ns}}$ & $1.07^{\mathrm{ns}}$ & $441.3^{\mathrm{ns}}$ & $789.9^{\mathrm{ns}}$ & $560.3^{* *}$ \\
Error a & 2 & 0.006 & 7.26 & 70.9 & 110.6 & 3.80 \\
AMF (M) & 3 & $0.006^{* * *}$ & $1.03^{* *}$ & $211.1^{* *}$ & $432.6^{* *}$ & $900.1^{* * *}$ \\
P $\times$ M & 6 & $0.013^{* *}$ & $1.24^{\mathrm{ns}}$ & $88.2^{*}$ & $170.5^{*}$ & $253.3^{* *}$ \\
Error b & 9 & 0.002 & 8.51 & 26.0 & 44.1 & 30.5 \\
Total & 23 & & & & & \\
\hline
\end{tabular}

Notes: *,**,***indicates significant at $0.05,0.01$, and 0.001 probability level respectively; $n s$ indicates not significant. 
Table 5. Effects of $\mathrm{P}$ fertilizer application $(\mathrm{P})$ and mycorrhizal inoculation $(\mathrm{M})$ on the concentration of nitrate, ureide, relative ureide- $\mathrm{N}$, the proportion of $\mathrm{N}$ derived from atmosphere, and the amount of $\mathrm{N}$ fixed in soybean

\begin{tabular}{lccccc}
\hline & $\begin{array}{c}\text { Nitrate-N } \\
(\mu \mathrm{mol})\end{array}$ & $\begin{array}{c}\text { Ureide-N } \\
(\mu \mathrm{mol})\end{array}$ & $\begin{array}{c}\text { Relative } \\
\text { ureide-N } \\
(\%)\end{array}$ & $\begin{array}{c}\text { Ndfa } \\
(\%)\end{array}$ & $\begin{array}{c}\text { Amount of N } \\
\text { fixed } \\
\left(\mathrm{kg} \mathrm{ha}^{-1}\right)\end{array}$ \\
\hline P rates (P) & 0.32 & 0.028 & 27.3 & 27.4 & 18.7 \\
$0 \mathrm{~kg} \mathrm{ha}^{-1}$ & 0.26 & 0.033 & 35.3 & 38.1 & 32.2 \\
$20 \mathrm{~kg} \mathrm{ha}^{-1}$ & 0.20 & 0.036 & 42.2 & 47.3 & 34.0 \\
$40 \mathrm{~kg} \mathrm{ha}^{-1}$ & $\mathrm{~ns}$ & $\mathrm{Ns}$ & 18.1 & $\mathrm{~ns}$ & 4.19 \\
Lsd (p < 0.05) & & & & & \\
AMF inoculation & 0.37 & 0.029 & 26.9 & 25.8 & 12.6 \\
Non-AMF & 0.24 & 0.037 & 38.9 & 43.2 & 35.7 \\
F. mosseae & 0.22 & 0.035 & 39.9 & 44.2 & 40.0 \\
R. intraradices & 0.23 & 0.029 & 34.1 & 37.1 & 24.8 \\
C. etunicatum & 0.07 & 0.004 & 6.66 & 8.67 & 7.21 \\
Lsd (p < 0.05) & & & & & \\
\hline
\end{tabular}

Note: $n$ indicates non-significant differences at $\mathrm{p}$ value $<0.05$.

There were interactive effects of $\mathrm{P}$ fertilizer rates and AMF inoculation on the concentration of nitrate-N, relative ureide-N, Ndfa, and nitrogen fixed in the soybean plants (Table 4). The concentration of nitrate- $\mathrm{N}$ was observed to significantly reduce with $\mathrm{AMF}$ inoculation under zero $\mathrm{P}\left(0 \mathrm{~kg} \mathrm{P}_{2} \mathrm{O}_{5} \mathrm{ha}^{-1}\right)$ and low $\mathrm{P}$ fertilizer $\left(20 \mathrm{~kg} \mathrm{P}_{2} \mathrm{O}_{5} \mathrm{ha}^{-1}\right)$ application, but no significant difference was observed at high $\mathrm{P}$ rate (Figure 3). The highest concentration of nitrate-N was observed in uninoculated soybean plants under zero $\mathrm{P}$ application $(0.49 \mu \mathrm{mol})$ and $20 \mathrm{~kg} \mathrm{P}_{2} \mathrm{O}_{5} \mathrm{ha}^{-1}(0.44 \mu \mathrm{mol})$ (Figure 3$)$.

The relative ureide- $\mathrm{N}$ of AMF-inoculated soybean was observed to significantly increase under zero $\mathrm{P}$ and low $\mathrm{P}$ application rates compared to nonAMF soybean plants; however, no difference was observed at high $\mathrm{P}$ rate (Figure 4). Soybean plants inoculated with $F$. mosseae had the highest relative ureide-N at zero $\mathrm{P}$ rate, while those inoculated with $R$. intraradices had the highest relative ureide- $\mathrm{N}$ at $20 \mathrm{~kg} \mathrm{P}_{2} \mathrm{O}_{5} \mathrm{ha}^{-1}$ and $40 \mathrm{~kg} \mathrm{P}_{2} \mathrm{O}_{5}$ ha $^{-1}$ application rates (Figure 4). 


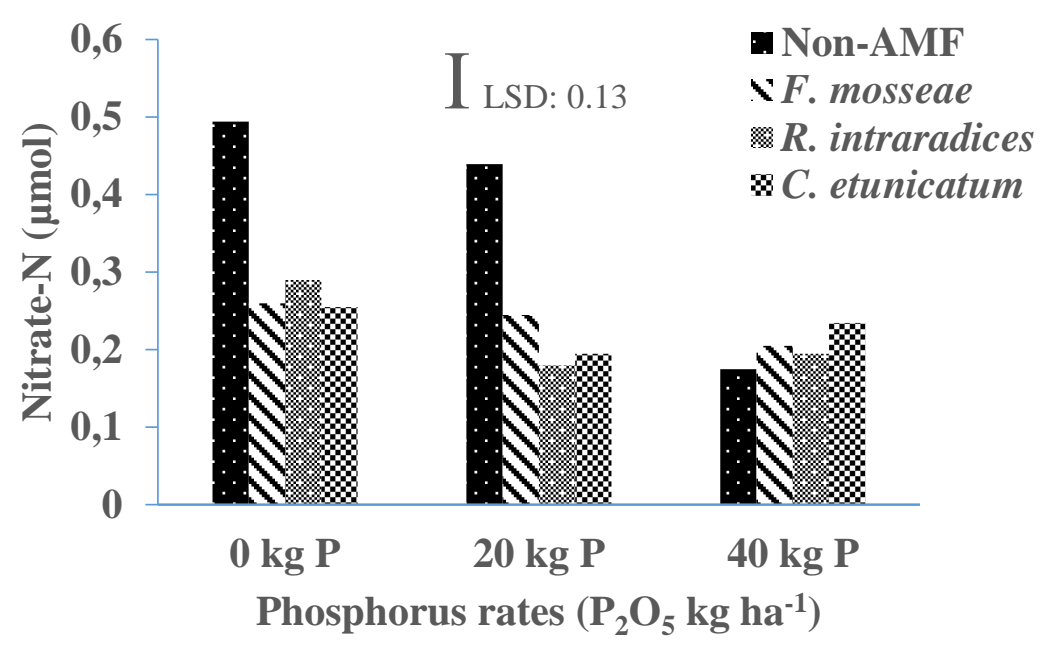

Figure 3. Interactive effect of phosphorus rates and AMF inoculation on nitrate-N of soybean. Bar denotes Lsd value at 5\% probability level.

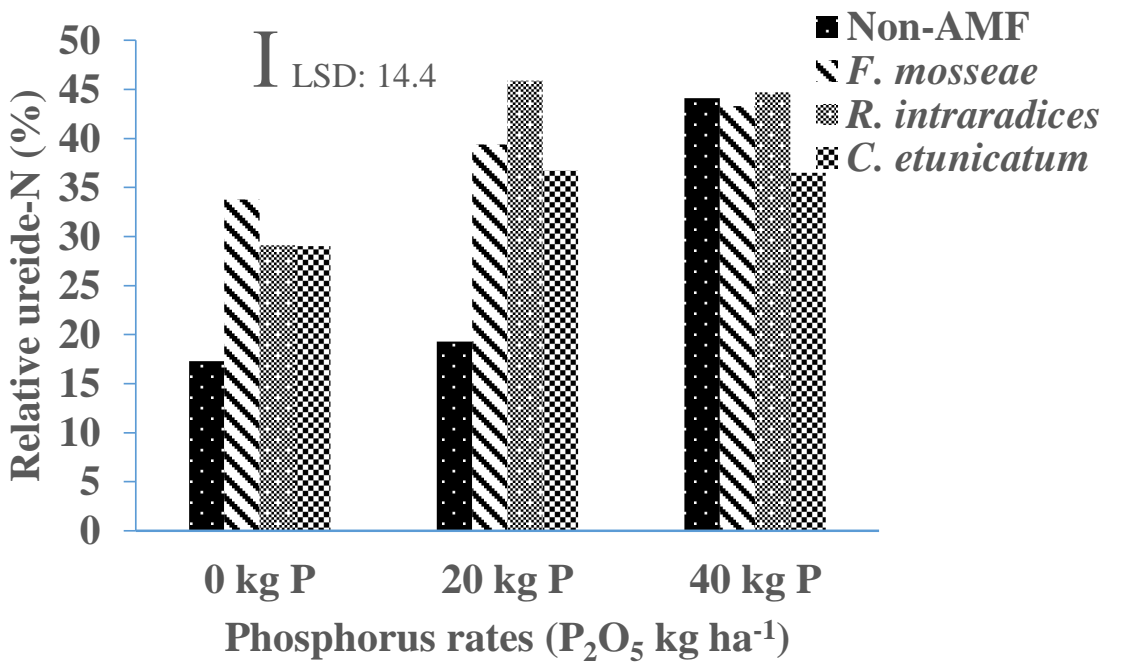

Figure 4. Interactive effect of phosphorus rates and AMF inoculation on relative ureide$\mathrm{N}$ of soybean. Bar denotes Lsd value at $5 \%$ probability level.

The Ndfa was recorded to increase with the inoculation of the three AMF isolates under zero $\mathrm{P}$ and low $\mathrm{P}$ application rates compared to non-AMF soybean plants, while under high $P$ rate no significant difference was observed among the $\mathrm{AMF}$ and non-AMF treatments (Figure 5). The highest Ndfa was observed in soybean inoculated with $R$. intraradices fertilized with $20 \mathrm{~kg} \mathrm{P}_{2} \mathrm{O}_{5} \mathrm{ha}^{-1}$. 


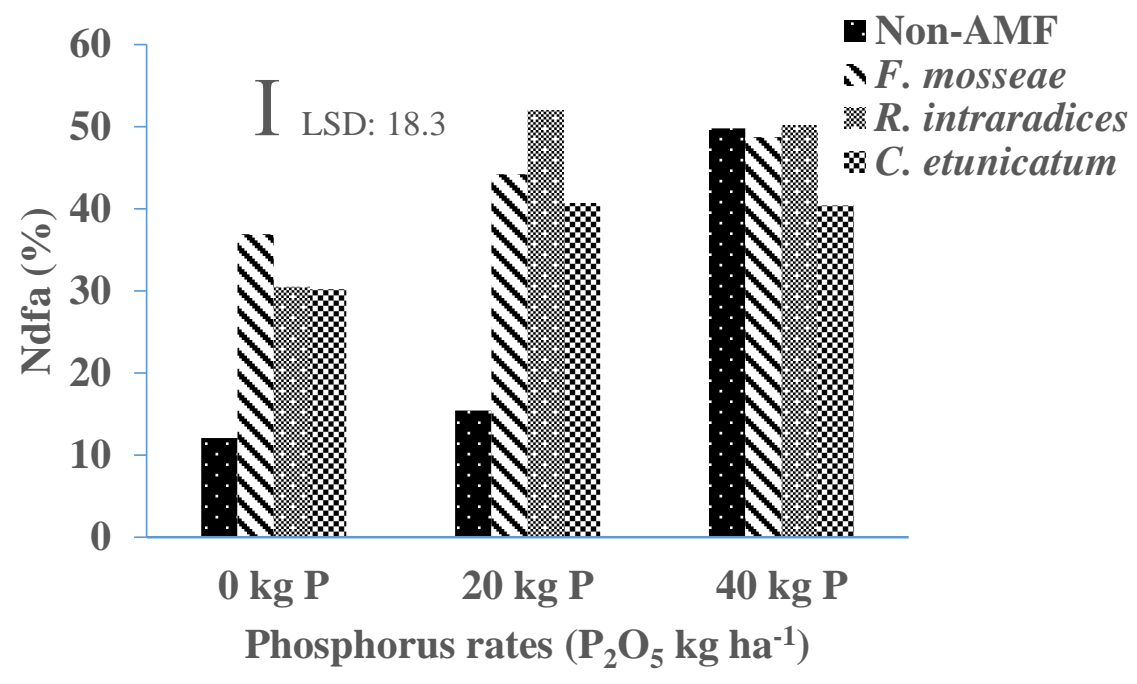

Figure 5. Interactive effect of phosphorus rates and AMF inoculation on $\mathrm{N}$ derived from atmosphere (\% Ndfa) of soybean. Bar denotes Lsd value at 5\% probability level.

Soybean plant inoculated with $R$. intraradices fertilized with $20 \mathrm{~kg} \mathrm{P}_{2} \mathrm{O}_{5}$ ha $^{-}$ ${ }^{1}$ had the highest amount of $\mathrm{N}$ fixed $\left(59.4 \mathrm{~kg} \mathrm{ha}^{-1}\right)$, while the lowest (2.4 and 3.8 $\mathrm{kg} \mathrm{ha}^{-1}$ ) was recorded in zero $\mathrm{P}$ and low $\mathrm{P}$ fertilizer application (Figure 6).

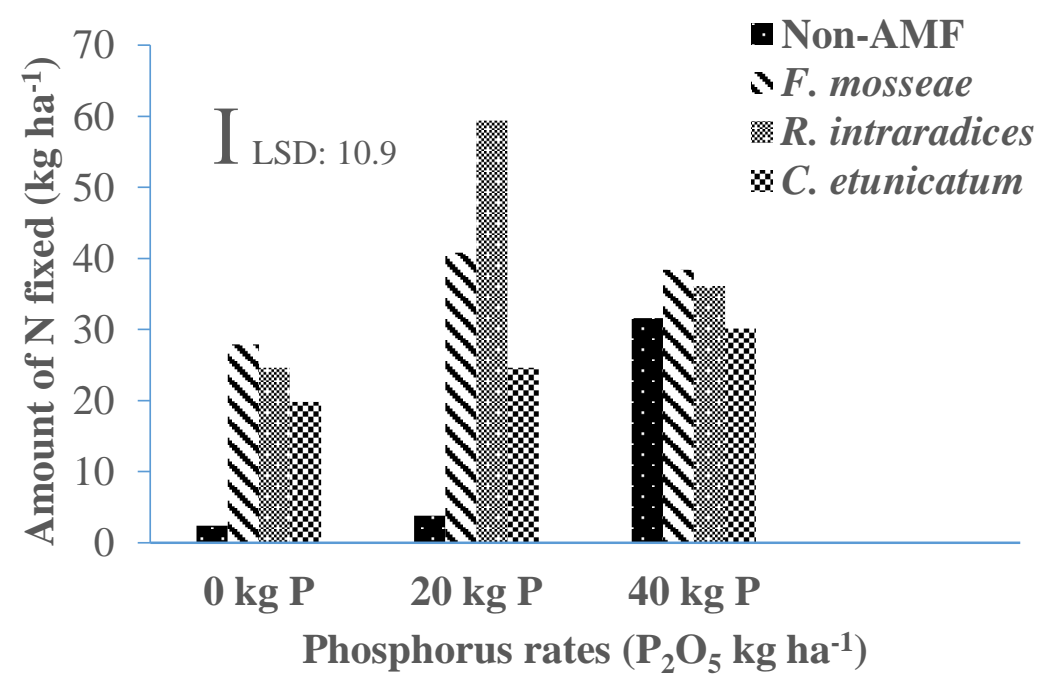

Figure 6. Interactive effect of phosphorus rates and AMF inoculation on the amount of $\mathrm{N}$ fixed by soybean. Bar denotes Lsd value at $5 \%$ probability level. 


\section{AMF root colonization}

AMF root colonization was significantly affected by $\mathrm{P}$ fertilizer rates, AMF inoculation, and the interactive effect between the treatments (Table O). There was a decrease in AMF root colonization with increase in $\mathrm{P}$ rates. The application of $40 \mathrm{~kg} \mathrm{P}_{2} \mathrm{O}_{5} \mathrm{ha}^{-1}$ rate significantly reduced the AMF root colonization by $55.1 \%$ compared to $20 \mathrm{~kg} \mathrm{P}_{2} \mathrm{O}_{5} \mathrm{ha}^{-1}$ (10\%) relative to the zero $\mathrm{P}$ fertilizer rate; however, no significant difference was observed in the AMF root colonization of the soybean between zero $\mathrm{P}$ and $20 \mathrm{~kg} \mathrm{P}_{2} \mathrm{O}_{5}$ ha $^{-1}$ fertilizer rate (Table 7). Significant difference was observed among the AMF isolates and non-AMF treatments on the root colonization of the soybean (Table 6). The lowest root colonization (15.3\%) was observed in non-AMF treatment, while soybean inoculated with $R$. intraradices had the highest root colonization (62.7\%), followed by $F$. mosseae (58.7\%) and C. etunicatum (48\%) (Table 7).

Table 6. Mean squares for the effect of $\mathrm{P}$ fertilizer application $(\mathrm{P})$ and mycorrhizal inoculation $(\mathrm{M})$ and their interactions $(\mathrm{P} \times \mathrm{M})$ on $\mathrm{AMF}$ root colonization, shoot $\mathrm{N}$ and $\mathrm{P}$ content, and grain and biomass yield of soybean

\begin{tabular}{lcccccc}
\hline & Df & $\begin{array}{c}\text { AMF root } \\
\text { colonization } \\
(\%)\end{array}$ & $\begin{array}{c}\text { Shoot N } \\
\text { uptake } \\
\left(\mathrm{kg} \mathrm{ha}^{-1}\right)\end{array}$ & $\begin{array}{c}\text { Shoot P } \\
\text { uptake } \\
\left(\mathrm{kg} \mathrm{ha}^{-1}\right)\end{array}$ & $\begin{array}{c}\text { Grain yield } \\
\left(\mathrm{kg} \mathrm{ha}^{-1}\right)\end{array}$ & $\begin{array}{c}\text { Biomass } \\
\text { yield } \\
\left(\mathrm{kg} \mathrm{ha}^{-1}\right)\end{array}$ \\
\hline Reps & 1 & 294.0 & 141.1 & 206.9 & 135219 & 106719 \\
P rates (P) & 2 & $2392.7 *$ & $179.8^{\mathrm{ns}}$ & $799.8^{*}$ & $2769766^{*}$ & $3421473^{*}$ \\
Error a & 2 & 114.0 & 128.1 & 17.6 & 73360 & 125881 \\
AMF (M) & 3 & $2765.1 * * *$ & $1525.5^{* * *}$ & $107.7 * * *$ & $998672 * * *$ & $1994264 * * *$ \\
P $\times$ M & 6 & $165.1 * * *$ & $290.4^{\mathrm{ns}}$ & $48.2^{* *}$ & $495792^{* * *}$ & $687066^{* * *}$ \\
Error b & 9 & 14.0 & 109.0 & 8.08 & 14303 & 63831 \\
Total & 23 & & & & & \\
\hline
\end{tabular}

Notes: *,**,***indicates significant at $0.05,0.01$, and 0.001 probability level, respectively; $\mathrm{ns}$ indicates not significant.

Regardless of the AMF treatments, the soybean root colonization was reduced at $40 \mathrm{~kg} \mathrm{P}_{2} \mathrm{O}_{5}$ ha $^{-1}$ fertilizer rate (Figure 7). 


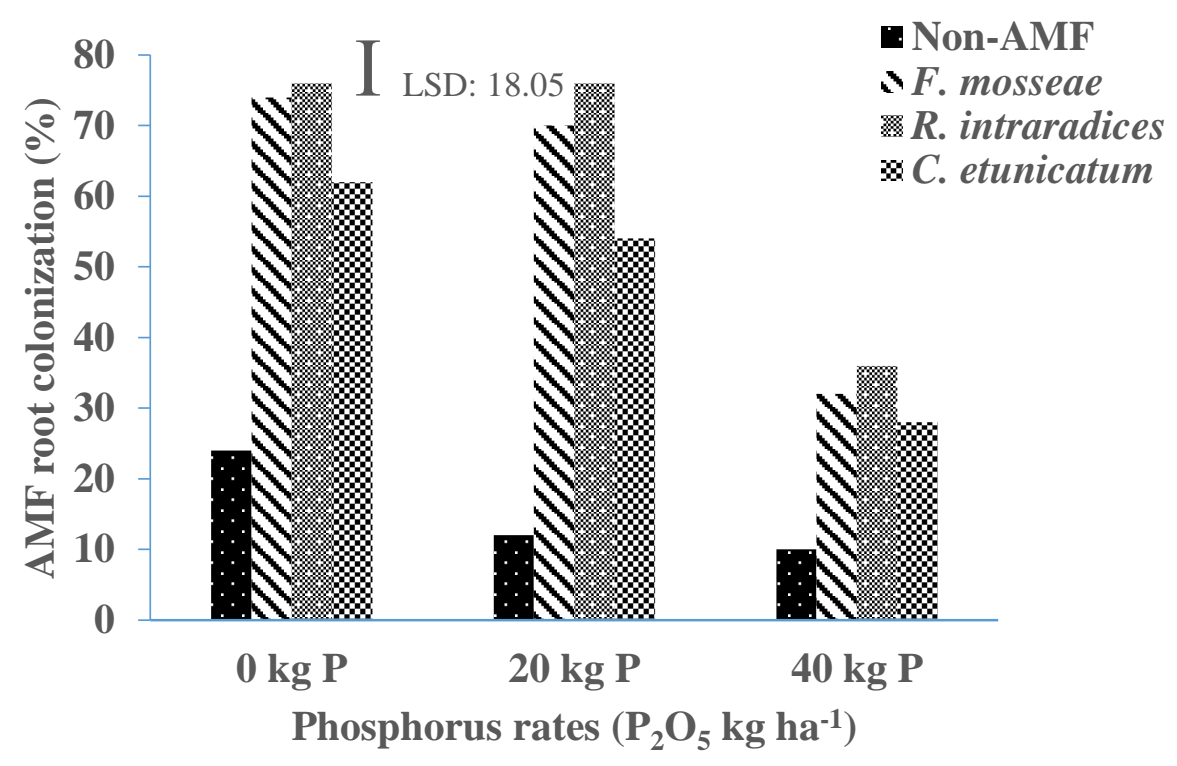

Figure 7. Interactive effect of phosphorus rates and AMF inoculation on AMF root colonization of soybean. Bar denotes Lsd value at $5 \%$ probability level.

\section{Shoot $N$ and $P$ content}

The soybean shoot $\mathrm{N}$ content was significantly influenced by AMF inoculation (Table 6). Significant difference was observed among the AMF isolates (Table 7). Inoculation with $R$. intraradices, $F$. mosseae, and $C$. etunicatum increased the soybean shoot $\mathrm{N}$ content by 59.7, 56.4, and $46.7 \%$, respectively, compared to non-AMF treatment. The shoot $\mathrm{P}$ content was significantly influenced by $\mathrm{P}$ fertilizer rates, AMF inoculation, and the interactive effect between the treatments (Table 6 ). Shoot $\mathrm{P}$ content increased with increase in $\mathrm{P}$ rates. Application of 20 and $40 \mathrm{~kg} \mathrm{P}_{2} \mathrm{O}_{5}$ ha $^{-1}$ rates increased shoot $\mathrm{P}$ content by 33.2 and $57.6 \%$, respectively, compared to zero $\mathrm{P}$ fertilizer rate (Table 7). Inoculation with $R$. intraradices, $F$. mosseae, and $C$. etunicatum increased the soybean shoot $\mathrm{P}$ content by $32.7,35.4$, and $27.9 \%$, respectively, compared to the non-AMF treatment, but no significant difference was observed among the AMF isolates (Table 7). With zero $\mathrm{P}$ and $20 \mathrm{~kg} \mathrm{P}_{2} \mathrm{O}_{5}$ ha $^{-1}$ fertilizer rates, the three AMF isolates increased the shoot $\mathrm{P}$ content of the soybean compared to the non-AMF treatment, while no difference was observed among the AMF treatments at $40 \mathrm{~kg}$ $\mathrm{P}_{2} \mathrm{O}_{5}$ ha $^{-1}$ fertilizer rate (Figure 8). 
Table 7. Effects of $P$ fertilizer application $(\mathrm{P})$ and mycorrhizal inoculation $(\mathrm{M})$ on AMF root colonization, shoot $\mathrm{N}$ and $\mathrm{P}$ content, and grain and biomass yield of soybean

\begin{tabular}{lccccc}
\hline & $\begin{array}{c}\text { AMF root } \\
\text { colonization } \\
(\%)\end{array}$ & $\begin{array}{c}\text { Shoot N } \\
\text { uptake } \\
\left(\mathrm{kg} \mathrm{ha}^{-1}\right)\end{array}$ & $\begin{array}{c}\text { Shoot P } \\
\text { uptake } \\
\left(\mathrm{kg} \mathrm{ha}^{-1}\right)\end{array}$ & $\begin{array}{c}\text { Grain yield } \\
\left(\mathrm{kg} \mathrm{ha}^{-1}\right)\end{array}$ & $\begin{array}{c}\text { Biomass } \\
\text { yield } \\
\left(\mathrm{kg} \mathrm{ha}^{-1}\right)\end{array}$ \\
\hline P rates (P) $\mathrm{kg} \mathrm{ha}^{-1}$ & 59.0 & 40.8 & 14.5 & 851 & 1899 \\
$20 \mathrm{~kg} \mathrm{ha}^{-1}$ & 53.0 & 48.8 & 21.7 & 1698 & 2779 \\
$40 \mathrm{~kg} \mathrm{ha}^{-1}$ & 26.5 & 49.4 & 34.2 & 1982 & 3177 \\
Lsd $(\mathrm{p}<0.05)$ & 22.9 & $\mathrm{Ns}$ & 9.03 & 582.7 & 763.3 \\
AMF inoculation & & & & & \\
Non-AMF & 15.3 & 24.2 & 17.3 & 991 & 1800 \\
F. mosseae & 58.7 & 55.5 & 25.7 & 1858 & 2974 \\
R. intraradices & 62.7 & 60.0 & 26.8 & 1813 & 3067 \\
C. etunicatum & 48.0 & 45.4 & 24.0 & 1782 & 2632 \\
Lsd (p < 0.05) & 4.89 & 13.6 & 3.71 & 156.2 & 330.0 \\
\hline
\end{tabular}

Note: $\mathrm{ns}$ indicates non-significant differences at $\mathrm{p}$ value $<0.05$.

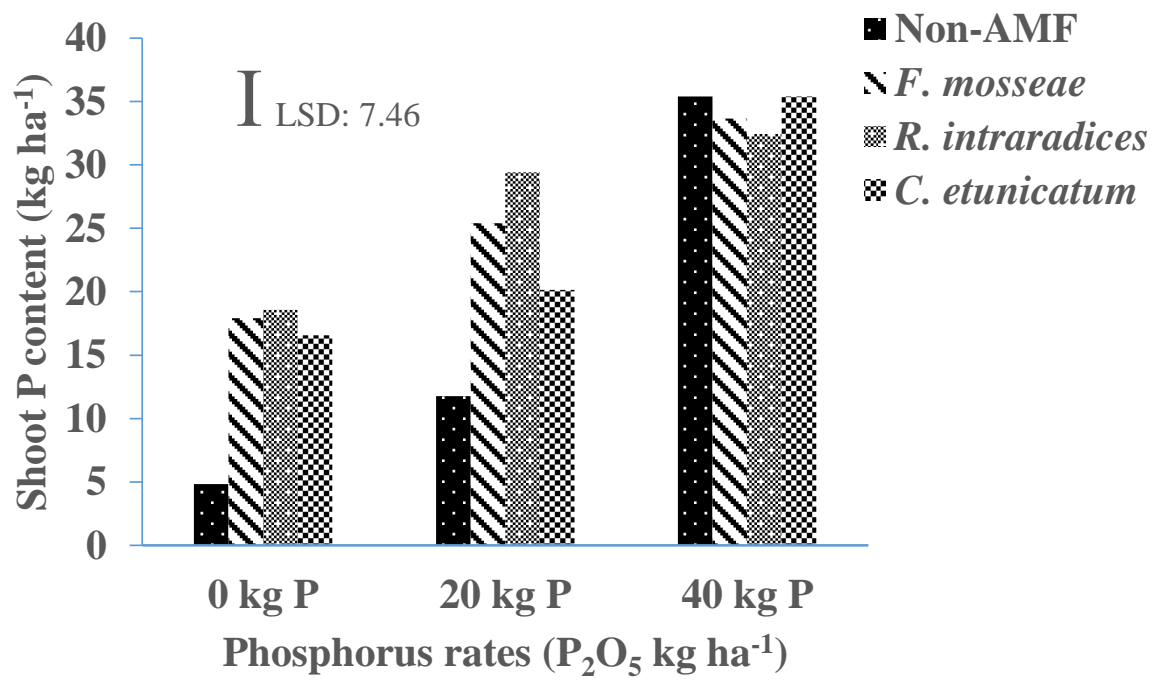

Figure 8. Interactive effect of phosphorus rates and AMF inoculation on the shoot phosphorus content of soybean. Bar denotes Lsd value at 5\% probability level. 


\section{Grain and biomass yields}

The results showed that the grain and biomass yield of the soybean were significantly influenced by $\mathrm{P}$ rates and AMF inoculation (Table 6 ). The grain and biomass yields increased with $\mathrm{P}$ rates (Table 7). Application of $40 \mathrm{~kg} \mathrm{P}_{2} \mathrm{O}_{5} \mathrm{ha}^{-1}$ rate increased the grain and biomass yields by 57.1 and $40.2 \%$, respectively, followed by $20 \mathrm{~kg} \mathrm{P}_{2} \mathrm{O}_{5} \mathrm{ha}^{-1}$ rate (49.9 and 31.7\%) compared to zero P fertilizer rate. Inoculation with $R$. intraradices, $F$. mosseae, and $C$. etunicatum increased the soybean grain yield by $46.7,45.3$, and $44.4 \%$, respectively, compared to the non-AMF treatment, but no significant difference was observed among the AMF isolates (Table 7). A similar pattern was observed with the biomass yield (Table 7). Significant interactions between $P$ fertilizer rates and AMF inoculation were observed for grain and biomass yield (Table 6 ). The highest grain yield was obtained in soybean inoculated with $R$. intraradices under $20 \mathrm{~kg} \mathrm{P}_{2} \mathrm{O}_{5} \mathrm{ha}^{-1}$ application rate, followed by $F$. mosseae under the same $\mathrm{P}$ treatment, while the lowest grain yield was recorded in the control plot as shown in Figure 9. For the biomass yield, soybean inoculated with $R$. intraradices and $F$. mosseae under 20 $\mathrm{kg} \mathrm{P}_{2} \mathrm{O}_{5} \mathrm{ha}^{-1}$ rate application gave the highest biomass yields, with the lowest one observed in the control plot (Figure 10).

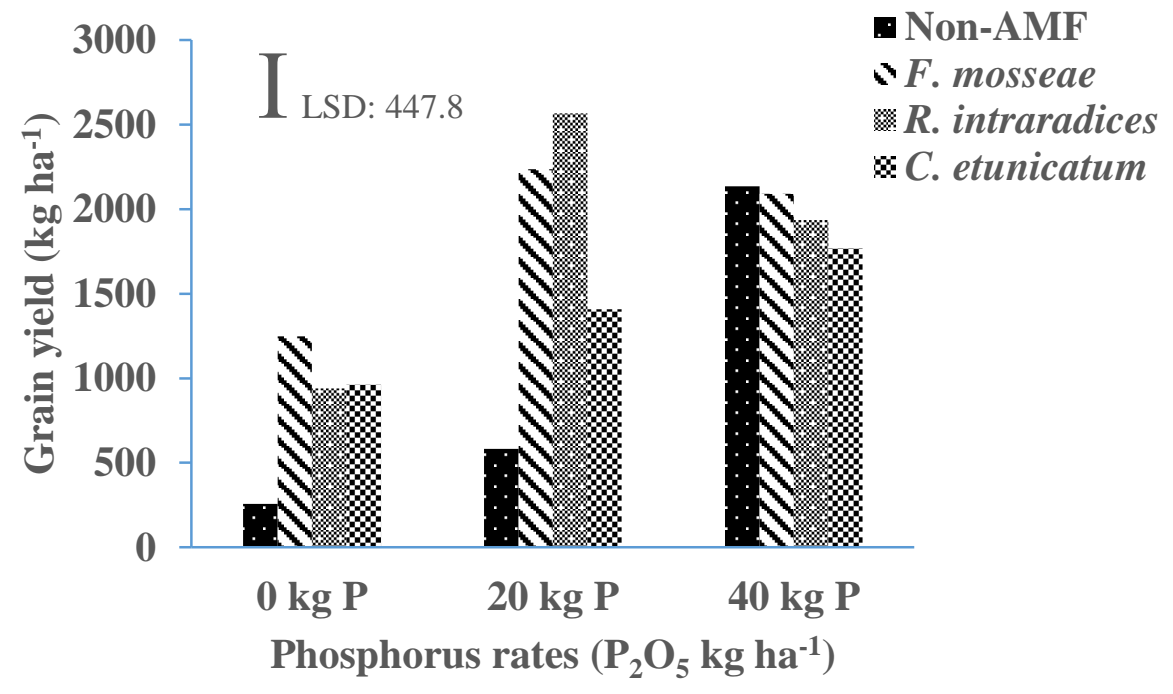

Figure 9. Interactive effect of phosphorus rates and AMF inoculation on the grain yield of soybean. Bar denotes Lsd value at $5 \%$ probability level. 


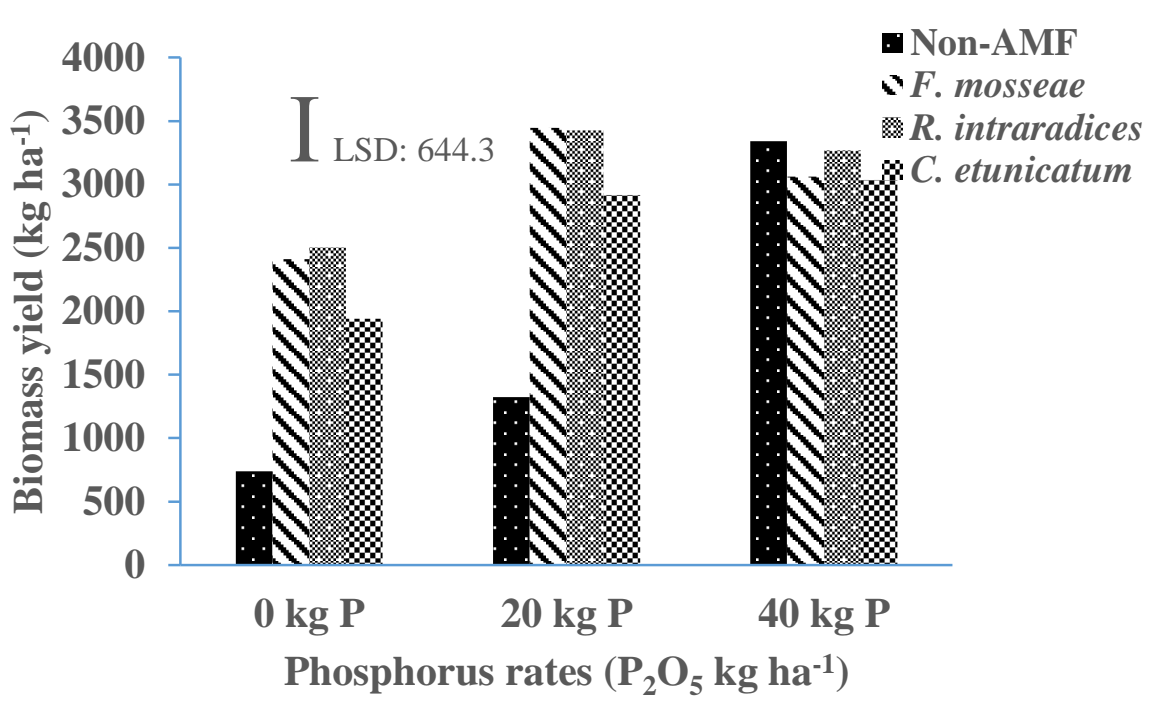

Figure 10. Interactive effect of phosphorus rates and AMF inoculation on the biomass yield of soybean. Bar denotes Lsd value at $5 \%$ probability level.

\section{Discussions}

The growth and yield performance of soybean improved with $\mathrm{P}$ fertilization. The increased shoot dry matter, number of nodules, and seed yield of the soybean are attributed to the increased $\mathrm{P}$ supply to the shoot $\mathrm{P}$, which is essential for many metabolic processes such as photosynthesis in the plants. $\mathrm{P}$ fertilization in legumes has been reported to increase $\mathrm{P}$ content in the nodules and shoot, with increased dry matter accumulation and grain yield [35]. The poor nodulation in terms of number of nodules and the nodule weight of the soybean with low available $\mathrm{P}$ could be attributed to the inability of the plant to partition sufficient $\mathrm{P}$ for nodule development [36]. This confirmed the reports of [37] that $\mathrm{P}$ deficiency reduced the number of nodules and weight in legumes. The relative ureide- $\mathrm{N}$ and the amount of $\mathrm{N}$ fixed in the soybean plants were improved with $\mathrm{P}$ fertilization compared to P-deficient plants in this present study. This is attributed to the increased concentration of ureides and reduced nitrate- $\mathrm{N}$ with $\mathrm{P}$ fertilization levels. P deficiency has been reported to reduce ureide translocation in the xylem sap, thus reducing nitrogen fixation potential [38]. The increased relative ureides$\mathrm{N}$ with increasing $\mathrm{P}$ fertilization resulted in high $\mathrm{N}_{2}$ fixation observed in this study. Low $\mathrm{P}$ availability is reported to reduce nitrate reductase activity in roots, which restricts nitrate transport from roots to shoots in P-deficient soybean plants $[39,40]$. Low $\mathrm{P}$ availability has been reported to reduce the supply of $\mathrm{C}$ from photosynthesis to the nodules [41]. The report of [42] showed that nodule 
construction cost and growth respiration of different legume plants increased with $\mathrm{P}$ deficiency. Furthermore, this study demonstrated increased shoot $\mathrm{N}$ content with increased $P$ fertilization levels. This corroborates the evidence from [11], who reported increased $\mathrm{N}_{2}$ fixation with $\mathrm{P}$ fertilization. Based on the above evidence, the low grain and biomass yield of the soybean could be attributed to the reduced dry matter accumulation and nitrogen fixation under $\mathrm{P}$ deficiency conditions.

The present study showed the increased root colonization of the soybean in all the AMF isolates used. This suggests the adaptability and higher competitiveness of AMF isolates with the indigenous mycorrhizal population and the soybean cultivar. The positive effects of AMF inoculation on the dry matter and grain yield of the soybean observed in this study corroborate several other reports under field conditions [43, 20]. Several reports showed that AMF promoted plant growth through increased $\mathrm{P}$ uptake $[44,45]$, which also confirmed the result of this study with high shoot $\mathrm{P}$ uptake in AMF-inoculated plants compared to the non-AMF control plants. The main benefit of AMF symbiosis with plants is the enhancement of $\mathrm{P}$ by the extra-radicular hyphae [14]. The increased $\mathrm{N}_{2}$ fixation in the soybean plants with $\mathrm{AMF}$ inoculation in this study could be attributed to the improved $\mathrm{P}$ uptake in mycorrhizal inoculated plants, thus enhancing the transport of ureide- $\mathrm{N}$ in the xylem.

The AMF isolates used for this study ( $F$. mosseae, $R$. intraradices, and $C$. etunicatum) are generalist AMF widely distributed in most P-deficient soils and can colonize a wide variety of host plants, including legumes [46]. The root colonization of soybean plants by AMF isolates was reduced at high $\mathrm{P}$ fertilization levels. High soil $\mathrm{P}$ availability has been reported to reduce AMF root colonization and hyphae development $[14,47]$. In contrast, the application of $P$ has been reported to promote mycorrhizal development in P-deficient soils [48]. This confirmed the result observed upon the application of $20 \mathrm{~kg} \mathrm{P}_{2} \mathrm{O}_{5} \mathrm{ha}^{-1}$ in this study. Among the three AMF tested, $R$. intraradices and $F$. mosseae had the best effect on plant performance in terms of phosphorus uptake, dry matter accumulation, nodulation, nitrogen fixation, and the yield performance of the soybean. The increased growth performance and nitrogen fixation in soybean inoculated with $R$. intraradices and $F$. mosseae could be attributed to their high ability in shoot $\mathrm{P}$ uptake $[49,50,51]$.

\section{Conclusions}

The findings demonstrated the potential of field inoculation with compatible and effective arbuscular mycorrhizal isolates in increasing phosphorus, nodulation, nitrogen fixation, and the grain yield of soybean. Among the three AMF isolates, Rhizophagus intraradices and Funneliformis mosseae gave higher 
nodulation and nitrogen fixation of the soybean. Therefore, to ensure higher soybean productivity and sustainable agriculture with reduced high input of chemical P fertilizer through nitrogen fixation, the inoculation of soybean with Rhizophagus intraradices or Funneliformis mosseae (combined with $20 \mathrm{~kg}_{2} \mathrm{O}_{5}$ $\mathrm{ha}^{-1}$ ) could be recommended, thus ameliorating the negative effect of $\mathrm{P}$ deficiency on soybean productivity in the derived savannah of Nigeria. This study was limited to a single soybean variety and a year's field study in one location. It is recommended that further field studies should be undertaken in multi-location sites and different seasons, which will be a significant step towards the stable use of mycorrhizal fungi inoculation for promoting legume productivity in most agricultural soils of Nigeria.

\section{References}

[1] FAOSTAT. (2017), Retrieved from: http://www.fao.org/faostat. Accessed on: 20 November 2017.

[2] Sharma, S., Sayyed, R. Z., Trivedi, M. H., Gobi, T. A. (2013), Phosphate solubilizing microbes: Sustainable approach for managing phosphorus deficiency in agricultural soils. SpringerPlus 2(1), 587.

[3] Bargaz, A., Ghoulam, C., Faghire, M., Attar, H. A., Drevon, J.-J. (2011), The nodule conductance to $\mathrm{O}_{2}$ diffusion increases with high phosphorus content in the Phaseolus vulgaris-rhizobia symbiosis. Symbiosis 53, 157-164.

[4] Khan, M. S., Zaidi, A., Ahemad, M., Oves, M., Wani, P. A. (2010), Plant growth promotion by phosphate solubilizing fungi - Current perspective. Archives of Agronomy and Soil Science 56(1), 73-98.

[5] Hernández, I., Munné-Bosch, S. (2015), Linking phosphorus availability with photooxidative stress in plants. J. Exp. Bot. 66(10), 2889-2900.

[6] Sulieman, S., Schulze, J., Tran, L.-S. P. (2014), N-feedback regulation is synchronized with nodule carbon alteration in Medicago truncatula under excessive nitrate or low phosphorus conditions. J. Plant Physiol. 171, 407-410.

[7] Nasr Esfahani, M. N., Kusano, M., Nguyen, K. H., Watanabe, Y., Van Ha, C., Saito, K., Sulieman, S., Herrera-Estrella, L., Tran, L.-S. P. (2016), Adaptation of the symbiotic Mesorhizobium-chickpea relationship to phosphate deficiency relies on reprogramming of whole-plant metabolism. Proc. Natl. Acad. Sci. 113, 4610-4619. DOI: 10.1073/pnas. 1609440113.

[8] Sulieman, S., Tran, L.-S. P. (2015). Phosphorus homeostasis in legume nodules as an adaptive strategy to phosphorus deficiency. Plant Sci. 239, 36-43. DOI:10.1016/j.plantsci. 2015.06.018.

[9] Almeida, J. P. F., Hartwig, U. A., Frehner, M., Nösberger, J., Lüscher, A. (2000). Evidence that $\mathrm{P}$ deficiency induces $\mathrm{N}$ feedback regulation of symbiotic $\mathrm{N}_{2}$ fixation in white clover (Trifolium repens L.). Journal of Experimental Botany 51, 1289-1297. DOI: 10.1093/jexbot/ 51.348.1289.

[10] Hernández, G., Valdés-López, O., Ramírez, M., Goffard, N., Weiller, G., Aparicio-Fabre, R., Fuentes, S. I., Erban, A., Kopka, J., Udvardi, M. K., Vance, C. P. (2009), Global changes in the transcript and metabolic profiles during symbiotic nitrogen fixation in phosphorusstressed common bean plants. Plant Physiol. 151, 1221-1238. DOI: 10.1104/ pp.109.143842. 
[11] Richardson, A. E., Simpson, R. J. 2011. Soil microorganisms mediating phosphorus availability update on microbial phosphorus. Plant Physiol. 56, 989-996. DOI: 10.1104/pp.111.175448.

[12] Naseer, M., Muhammad, D. (2014), Direct and residual effect of Hazara rock phosphate (Hrp) on wheat and succeeding maize in alkaline calcareous soils. Pak. J. Bot. 46(5), $1755-1761$.

[13] da Costa, E. M., de Lima, W., Oliveira-Longatti, S. M., de Souza, F. M. (2015), Phosphatesolubilising bacteria enhance Oryza sativa growth and nutrient accumulation in an oxisol fertilized with rock phosphate. Ecological Engineering 83, 380-385.

[14] Smith, S. E., Read, D. (2008), The symbionts forming arbuscular mycorrhizas In: Smith, S. E., Read, D. (eds.), Mycorrhizal symbiosis, $3^{\text {rd }}$ edition. New York: Academic Press. 13-41.

[15] Neumann, E., George, E. (2010), Nutrient uptake: The arbuscular mycorrhiza fungal symbiosis as a plant nutrient acquisition strategy. In: Arbuscular mycorrhizas: Physiology and function. Dordrecht: Springer Netherlands. 137-167.

[16] Bhardwaj, D., Ansari, M. W., Sahoo, R. K., Tuteja, N. (2014), Biofertilizers function as key player in sustainable agriculture by improving soil fertility, plant tolerance and crop productivity. Microbial Cell Factories 13(1), 10.

[17] Berruti, A., Lumini, E., Balestrini, R., Bianciotto, V. (2016), Arbuscular mycorrhizal fungi as natural biofertilizers: Let's benefit from past successes. Frontiers in Microbiology 6, $1-13$.

[18] Sakariyawo, O. S., Adeyemi, N. O., Atayese, M. O., Aderibigbe S. G. (2016), Growth, assimilate partitioning and grain yield response of soybean (Glycine max L. Merrrill) varieties to carbon dioxide enrichment and arbuscular mycorrhizal fungi in the humid rainforest. Agro-Science 15, 29-40.

[19] Adeyemi, N., Sakariyawo, O., Atayese, M. (2017), Yield and yield attributes responses of soybean (Glycine max L. Merrill) to elevated $\mathrm{CO}_{2}$ and arbuscular mycorrhizal fungi inoculation in the humid transitory rainforest. Notulae Scientia Biologicae 9(2), 233-241. DOI: $10.15835 / \mathrm{nsb} 9210002$.

[20] Adeyemi, N. O., Atayese, M. O., Olubode, A. A., Akan, M. E. (2020), Effect of commercial arbuscular mycorrhizal fungi inoculant on growth and yield of soybean under controlled and natural field conditions. Journal of Plant Nutrition 43(4), 487-499. DOI: 10.1080/01904167. 2019.1685101.

[21] Ardakani M. R., Pietsch, G., Moghaddam, A., Raza, A., Friedel, J. K. (2009), Response of root properties to tripartite symbiosis between lucerne (Medicago sativa L.), rhizobia and mycorrhiza under dry organic farming conditions. Am. J. Agric. Biol. Sci. 4, $266-277$.

[22] Antunes, P. M., De Varennes, A., Rajcan, I., Goss, M. J. (2006), Accumulation of specific flavonoids in soybean (Glycine $\max$ (L.) Merr.) as a function of the early tripartite symbiosis with arbuscular mycorrhizal fungi and Bradyrhizobium japonicum (Kirchner) Jordan. Soil Biol. Biochem. 38, 1234-1242.

[23] McLean, E. O. (1982), Soil pH and lime requirement. Methods of Soil Analysis. Part 2. Chemical and Microbiological Properties (methodsofsoilan2). 199-224.

[24] Allison, L. (1965), Organic carbon. In: Black, C. A. (ed.), Methods of soil analysis. Part 2. Madison: American Society of Agronomy. 1307-1378.

[25] Jackson, M. (1962), Soil chemical analysis. New Delhi: Prentice Hall of India Pvt, Ltd.

[26] Bray, R., Kurtz, L. (1945), Determination of total, organic and available forms of phosphorus in soil. Soil Science 59, 39-45.

[27] Murphy, J., Riley, J. P. (1962), A modified single solution method for the determination of phosphorus in natural waters. Analytical Chemical Acta 27, 31-36.

[28] Bouyoucuos, G. (1962), Hydrometer method improved for making particle size analysis of soil. Agronomy Journal 54, 464-465. 
[29] Giovanetti, M., Mosse, B. (1980), An evaluation of techniques for measuring vesicular arbuscular mycorrhizal infection in roots. New Phytologist 84, 489-500.

[30] Peoples, M. B., Hebb, D. M., Gibson, A. H., Herridge, D. F. (1989), Development of the xylem ureide assay or the measurement of nitrogen fixation by pigeon pea (Cajanus cajan (1.) Millsp.). Journal of Experimental Botany 40, 535-542.

[31] Young, E. G., Conway, C. F. (1942), On the estimation of allantoin by the rimini-schryver reaction. Journal of Biological Chemistry 142, 839-853.

[32] Cataldo, D. A., Haroon, M., Schrader, L. E., Youngs, V. L. (1975), Rapid colorimetric determination of nitrate in plant tissue by nitration of salicylic acid. Communications Soil Science Plant Analysis 6, 71-80.

[33] Rochester, I., Peoples, M., Constable, G. A., Gault, R. (1998), Faba beans and other legumes add nitrogen to irrigated cotton cropping systems. Australian Journal of Experimental Agriculture 38, 253-260.

[34] Phillips, J. M., Hayman, D. S. (1970), Improved procedures for clearing roots and staining parasitic and vesicular arbuscular mycorrhizal fungi for rapid assessment of infection. T. Brit. Mycol. Soc. 55, 158-161.

[35] Olivera, M., Tejera, N., Iribarne, C., Ocaña, A., Lluch, C. (2004), Growth, nitrogen fixation and ammonium assimilation in common bean (Phaseolus vulgaris): Effect of phosphorus. Physiol. Plant 121, 498-505. DOI: 10.1111/j.0031-9317.2004.00355.x.

[36] Sulieman, S., Ha, C. V., Schulze, J., Tran, L.-S. P. (2013), Growth and nodulation of symbiotic Medicago truncatula at different levels of phosphorus availability. J. Exp. Bot. 64(10), 2701-2712. DOI: 10.1093/jxb/ert122.

[37] Bargaz, A., Faghire, M., Farissi, M., Drevon, J.-J., Ghoulam, C. (2013), Oxidative stress in the root nodules of Phaseolus vulgaris is induced under conditions of phosphorus deficiency. Acta Physiol. Plant 35, 1633-1644.

[38] Sa, T. M., Israel, D. W. (1995), Nitrogen assimilation in nitrogen-fixing soybean plants during phosphorus deficiency. Crop Science 35(3), 814-820.

[39] Rufty, T. W., Israel, D. W., Volk, R. J., Qiu, J., Sa, T. (1993), Phosphate regulation of nitrate assimilation in soybean. Journal Experimental Botany 44, 879-891.

[40] Ribet, J., Drevon, J. J. (1995). Increase in conductance to oxygen and in oxygen uptake of soybean nodules under limiting phosphorus nutrition. Physiol. Plant 94, 298-304.

[41] Valentine, A. J., Benedito, V. A., Kang, Y. (2011), Legume nitrogen fixation and soil biotic stress: From physiology to genomics and beyond. Annu. Plant Rev. 42, 207-248.

[42] Vardien, W., Mesjasz-Przybylowicz, J., Przybylowicz, W. J., Wang, Y. D., Steenkamp, E. T., Valentine, A. J. (2014), Nodules from Fynbos legume Virgilia divaricata have high functional plasticity under variable P supply levels. J. Plant Physiol. 171, 1732-1739.

[43] Cely, M. V. T., de Oliveira, A. G., de Freitas, V. F., de Luca, M. B., Barazetti, A. R., dos Santos, I. M. O., Gionco, B., Garcia, G. V., Prete, C. E. C., Andrade, G. (2016), Inoculant of arbuscular mycorrhizal fungi (Rhizophagus clarus) increase yield of soybean and cotton under field conditions. Frontiers in Microbiology 7, 1-9.

[44] Asghari, H. R., Cavagnaro, T. R. (2011), Arbuscular mycorrhizas enhance plant interception of leached nutrients. Funct. Plant Biol. 38, 219-226.

[45] Wu, X. Q., Hou, L. L., Sheng, J. M., Ren, J. H., Zheng, L., Chen, D., Ye, J. R. (2012), Effects of ectomycorrhizal fungus Boletus edulis and mycorrhiza helper Bacillus cereus on the growth and nutrient uptake by Pinus thunbergii. Biol. Fertil. Soils 48(4), 385-391.

[46] Öpik, M., Vanatoa, A., Vanatoa, E., Moora, M., Davison, J., Kalwij, J. M., Reier, Ü., Zobel, M. (2010), The online database MaarjAM reveals global and ecosystemic distribution patterns in arbuscular mycorrhizal fungi (Glomeromycota). New Phytologist 188(1), 223-241. 
[47] Balzergue. C., Puech-Pagès, V., Bécard, G., Rochange, S. F. (2010), The regulation of arbuscular mycorrhizal symbiosis by phosphate in pea involves early and systemic signalling events. J. Exp. Bot. 3, 1049-1060.

[48] Chalk, P. M., Souza, R. D. F., Urquiaga, S., Alves, B. J. R., Boddey, R. M. (2006), The role of arbuscular mycorrhiza in legume symbiotic performance. Soil Biology and Biochemistry 38(9), 2944-2951.

[49] Pellegrino, E., Bedini, S., Avio, L., Bonari, E., Giovannetti, M. (2011), Field inoculation effectiveness of native and exotic arbuscular mycorrhizal fungi in a Mediterranean agricultural soil. Soil Biology and Biochemistry 43(2), 367-376.

[50] Cozzolino, V., Di Meo, V., Piccolo, A. 2013. Impact of arbuscular mycorrhizal fungi applications on maize production and soil phosphorus availability. Journal of Geochemical Exploration 129, 40-44.

[51] Williams, A., Ridgway, H. J., Norton, D. A. (2013), Different arbuscular mycorrhizae and competition with an exotic grass affect the growth of Podocarpus cunninghamii Colenso cuttings. New Forests 44(2), 183-195. 